\title{
Thrombin generation and inactivation in the presence of antithrombin III and heparin
}

Citation for published version (APA):

Lindhout, T., Baruch, D., Schoen, P., Franssen, J., \& Hemker, H. C. (1986). Thrombin generation and inactivation in the presence of antithrombin III and heparin. Biochemistry, 25(20), 5962-5969. https://doi.org/10.1021/bi00368a019

Document status and date:

Published: 01/01/1986

DOI:

10.1021/bi00368a019

Document Version:

Publisher's PDF, also known as Version of record

\section{Please check the document version of this publication:}

- A submitted manuscript is the version of the article upon submission and before peer-review. There can be important differences between the submitted version and the official published version of record.

People interested in the research are advised to contact the author for the final version of the publication, or visit the DOI to the publisher's website.

- The final author version and the galley proof are versions of the publication after peer review.

- The final published version features the final layout of the paper including the volume, issue and page numbers.

Link to publication

\footnotetext{
General rights rights.

- You may freely distribute the URL identifying the publication in the public portal. please follow below link for the End User Agreement:

www.umlib.nl/taverne-license

Take down policy

If you believe that this document breaches copyright please contact us at:

repository@maastrichtuniversity.nl

providing details and we will investigate your claim.
}

Copyright and moral rights for the publications made accessible in the public portal are retained by the authors and/or other copyright owners and it is a condition of accessing publications that users recognise and abide by the legal requirements associated with these

- Users may download and print one copy of any publication from the public portal for the purpose of private study or research.

- You may not further distribute the material or use it for any profit-making activity or commercial gain

If the publication is distributed under the terms of Article $25 \mathrm{fa}$ of the Dutch Copyright Act, indicated by the "Taverne" license above, 


\title{
Thrombin Generation and Inactivation in the Presence of Antithrombin III and Heparin
}

\author{
Theo Lindhout,* Dominique Baruch, Pieter Schoen, Jo Franssen, and H. Coenraad Hemker \\ Department of Biochemistry, Biomedical Center, University of Limburg, Maastricht, The Netherlands
}

Received November 5, 1985; Revised Manuscript Received January 21, 1986

\begin{abstract}
We have determined the rate constants of inactivation of factor $\mathrm{X}_{\mathrm{a}}$ and thrombin by antithrombin III/heparin during the process of prothrombin activation. The second-order rate constant of inhibition of factor $X_{\mathrm{a}}$ alone by antithrombin III as determined by using the synthetic peptide substrate S-2337 was found to be $1.1 \times 10^{6} \mathrm{M}^{-1} \mathrm{~min}^{-1}$. Factor $\mathrm{X}_{\mathrm{a}}$ in prothrombin activation mixtures that contained prothrombin, and either saturating amounts of factor $\mathrm{V}_{\mathrm{a}}$ or phospholipid $(20 \mathrm{~mol} \%$ dioleoylphosphatidylserine $/ 80 \mathrm{~mol} \%$ dioleoylphosphatidylcholine, $10 \mu \mathrm{M}$ ), was inhibited by antithrombin III with a second-order rate constant that was essentially the same: $1.2 \times 10^{6} \mathrm{M}^{-1} \mathrm{~min}^{-1}$. When both factor $\mathrm{V}_{\mathrm{a}}$ and phospholipid were present during prothrombin activation, factor $X_{a}$ inhibition by antithrombin III was reduced about 10 -fold, with a second-order rate constant of $1.3 \times 10^{5} \mathrm{M}^{-1} \mathrm{~min}^{-1}$. Factor $\mathrm{X}_{\mathrm{a}}$ in the prothrombin activation mixture that contained both factor $\mathrm{V}_{\mathrm{a}}$ and phospholipid was even more protected from inhibition by the antithrombin III-heparin complex. The first-order rate constants of these reactions at $200 \mathrm{nM}$ antithrombin III and normalized to heparin at $1 \mu \mathrm{g} / \mathrm{mL}$ were 0.33 and $9.5 \mathrm{~min}^{-1}$ in the presence and absence of factor $V_{\mathrm{a}}$ and phospholipid, respectively. When the prothrombin concentration was varied widely around the $K_{\mathrm{m}}$ for prothrombin, this had no effect on the first-order rate constants of inhibition. It is our conclusion that factor $\mathrm{X}_{\mathrm{a}}$ when acting in prothrombinase on prothrombin is profoundly protected from inhibition by antithrombin III in the absence as well as in the presence of heparin. The second-order rate constant $\left(4.5 \times 10^{5} \mathrm{M}^{-1}\right.$ $\mathrm{min}^{-1}$ ) of inhibition of thrombin activity generated during prothrombin activation was found to be (1) constant during the time course of prothrombin activation, (2) independent of the composition of the prothrombin converting complex, and (3) about 4-fold lower than the second-order rate constant of inhibition of purified $\alpha$-thrombin $\left(1.9 \times 10^{6} \mathrm{M}^{-1} \mathrm{~min}^{-1}\right)$. Surprisingly, heparin hardly enhanced the antithrombin III dependent rate of inhibition of thrombin activity formed during the initial phase of the prothrombin activation. The apparent pseudo-first-order rate constant of this reaction at $200 \mathrm{nM}$ antithrombin III and normalized to heparin at $1 \mu \mathrm{g} / \mathrm{mL}$ was $0.10 \mathrm{~min}^{-1}$ and independent of the stage of thrombin production. The rate constant of the purified $\alpha$-thrombin/antithrombin III reaction, performed under the same conditions, was $25 \mathrm{~min}^{-1}$. This difference between the two reactions of thrombin inactivation is mainly caused by the fact that meizothrombin (des fragment 1), rather than $\alpha$-thrombin, is the major product during the initial phase of prothrombin activation.
\end{abstract}

$T_{\text {he }}$ proteases involved in the process of blood coagulation. Its action is dramatically enhanced by heparin. The main targets of antithrombin III are activated blood coagulation factor IX (factor $\mathrm{IX}_{\mathrm{a}}$ ), factor $\mathrm{X}_{\mathrm{a}}$, and thrombin [see Rosenberg (1982) and references cited therein].

The activation of prothrombin to thrombin is a membrane-mediated process requiring the binding of both factor $X_{a}$ and prothrombin to a negatively charged membrane surface (phospholipid vesicles). In addition, activated blood coagulation factor $\mathrm{V}$ (factor $\mathrm{V}_{\mathrm{a}}$ ) that interacts with the membrane, factor $\mathrm{X}_{\mathrm{a}}$, and prothrombin greatly increases the $V_{\max }$ of prothrombin activation and lowers the $K_{\mathrm{m}}$ for prothrombin when the membrane contains a low negative charge density [see van Rijn et al. (1984) and references cited therein]. Because in vivo both factor $\mathrm{V}_{\mathrm{a}}$ and phospholipids are present during factor $X_{a}$ catalyzed activation of prothrombin, a number of studies were undertaken to reveal the effects of these so-called accessory components on factor $\mathrm{X}_{\mathrm{a}}$ inhibition by antithrombin III. It has been shown that the inhibition of factor $\mathrm{X}_{\mathrm{a}}$ is reduced by phospholipids alone (Walker \& Esmon, 1979a; Ellis et al., 1984) and by phospholipids when factor $\mathrm{V}_{\mathrm{a}}$ is also present (Marciniak, 1973).

\footnotetext{
* Correspondence should be addressed to this author.
}

Ellis et al. (1984) used the rate of prothrombin activation as a measure for residual factor $X_{a}$ activity. Quite unexpectedly, the antithrombin III carried over in the prothrombin activation assay, as far as we understand, did not affect the thrombin activity nor factor $X_{\mathrm{a}}$. Walker and Esmon (1979b) reported that fragment 2 was found to slow down the rate of inhibition of $\alpha$-thrombin about 3 -fold. These observations provoke the investigation of the kinetics of the antithrombin III dependent neutralization of both factor $X_{a}$ and thrombin activity under more physiological conditions. Therefore, our purpose was to assess the kinetics of the antithrombin III dependent inhibition of factor $X_{a}$ as part of the prothrombinase complex while acting on prothrombin as well as the kinetics of the antithrombin III dependent inhibition of thrombin activity as a product of the prothrombinase reaction. The basic assumption underlying the data analysis of the experiments presented here was that at any time during the prothrombin activation reaction in the presence of antithrombin III, the observed rate of thrombin formation equals the actual rate of thrombin formation (proportional to the residual factor $\mathrm{X}_{\mathrm{a}}$ activity) minus the rate of inhibition of the thrombin activity. The same experiments were also performed in the presence of unfractionated heparin.

Our results lead us to question the validity of a number of basic assumptions underlying the current ideas about the ef- 
fects of factor $V_{a}$ and phospholipid on the factor $X_{a} /$ antithrombin III reaction. Furthermore, a dramatic discrepancy was found between the kinetics of the heparin-dependent inhibition of thrombin generated directly from prothrombin activation and the kinetics of heparin-dependent inhibition of $\alpha$-thrombin by antithrombin III.

\section{Materials ANd Methods}

Materials. Phosphatidylcholine (dioleoyl), soybean trypsin inhibitor, and fatty acid free human serum albumin were purchased from Sigma. H-D-Phenylalanyl-L-pipecolyl-L-arginine- $p$-nitroanilide dihydrochloride (S-2238) and benzoylL-isoleucyl-L-L-glutamyl(piperidyl)-L-glycyl-L-arginine- $p$ nitroanilide hydrochloride (S-2337) were obtained from Kabi $\mathrm{AB}$, Sweden. Crude heparin (165 USP units $/ \mathrm{mg}$ ) was generously provided by Pharmuka Laboratoires, France. All reagents used were of the highest grade commercially obtainable.

Proteins. Bovine antithrombin III was prepared by the method of Thaler and Schmer (1975). All other bovine clotting factors were prepared and quantitated as previously described (Lindhout et al., 1982).

Phospholipid Vesicle Preparation. 1,2-Dioleoyl-snglycero-3-phosphoserine (DOPS) was prepared from 1,2dioloeyl-sn-glycero-3-phosphocholine (DOPC) as described by Comfurius and Zwaal (1977). Sonicated vesicle solutions were prepared from mixtures of DOPS $(20 \mathrm{~mol} \%)$ and DOPC $(80$ mol \%) in a buffer that contained $50 \mathrm{mM}$ tris(hydroxymethyl)aminomethane hydrochloride (Tris- $\mathrm{HCl}) / 175 \mathrm{mM}$ $\mathrm{NaCl}, \mathrm{pH} 7.9$, as described by de Kruijff et al. (1975).

Determination of Inhibition Rate of Purified Proteases. The neutralization of factor $X_{a}$ and thrombin by antithrombin III was investigated under pseudo-first-order conditions. Factor $\mathrm{X}_{\mathrm{a}}$ or thrombin was incubated at $37^{\circ} \mathrm{C}$ in $50 \mathrm{mM}$ Tris- $\mathrm{HCl}, 175 \mathrm{mM} \mathrm{NaCl}$, and $0.5 \mathrm{mg}$ of human serum albumin $/ \mathrm{mL}, \mathrm{pH} 7.9$, with antithrombin III. At timed intervals after the addition of the protease, $10-\mu \mathrm{L}$ aliquots were removed into $590 \mu \mathrm{L}$ of substrate solution [containing $50 \mathrm{mM}$ Tris- $\mathrm{HCl}$, $175 \mathrm{mM} \mathrm{NaCl}, 20 \mathrm{mM}$ ethylenediaminetetraacetic acid (EDTA), $0.5 \mathrm{mg}$ of human serum albumin $/ \mathrm{mL}$, and $0.22 \mathrm{mM}$ S-2238 or S-2337, pH 7.9] at $37^{\circ} \mathrm{C}$. After $4 \mathrm{~min}, 300 \mu \mathrm{L}$ of $50 \%$ acetic acid (v/v) was added, and the absorbance of the mixture was measured at $405 \mathrm{~nm}$ against a blank by using an Aminco DW-2 spectrophotometer. The rates of thrombin and factor $X_{a}$ inhibition by antithrombin III after sampling into the substrate solution were found to be sufficiently slow so as to not result in measurable enzyme inhibition. The residual enzyme activity was calculated from a standard curve constructed under the same conditions from known amounts of thrombin or factor $X_{a}$ and exponentially plotted vs. reaction time.

Neutralization of Factor $X_{\mathrm{a}}$ and Thrombin by Antithrombin III in Prothrombin Activation Mixtures. Prothrombin was incubated with antithrombin III in the presence of either factor $\mathrm{V}_{\mathrm{a}}$, phospholipid vesicles, or heparin or a combination of these in $50 \mathrm{mM}$ Tris- $\mathrm{HCl}, 175 \mathrm{mM} \mathrm{NaCl}, 5$ or $10 \mathrm{mM} \mathrm{CaCl}_{2}$, and $0.5 \mathrm{mg}$ of human serum albumin $/ \mathrm{mL}, \mathrm{pH} 7.9$ at $37^{\circ} \mathrm{C}$, for $4 \mathrm{~min}$. Prothrombin activation was started by the addition of factor $X_{a}$. The final concentrations of the reaction components are listed in Table I. At timed intervals after the addition of factor $X_{a}, 40-\mu \mathrm{L}$ aliquots were removed into 560 $\mu \mathrm{L}$ of the aforementioned solutions of S-2238. Thrombin concentrations were determined as described before. In separate experiments, soybean trypsin inhibitor $(20 \mu \mathrm{g} / \mathrm{mL})$ was added to prothrombin activation mixtures at known intervals after the addition of factor $X_{a}$, resulting in an instantaneous and complete inhibition of thrombin formation. After the addition of soybean trypsin inhibitor, $40-\mu \mathrm{L}$ aliquots were removed at regular intervals and assayed for thrombin activity. Control experiments established that soybean trypsin inhibitor had no effect on the antithrombin III/thrombin reaction nor on the amidolytic activity of thrombin.

Kinetic Analysis of Antithrombin III/Factor $X_{\mathrm{a}}$ and Antithrombin III/Thrombin Reaction in Prothrombin Activation Mixtures. When thrombin is generated by prothrombinasecatalyzed activation of prothrombin in the presence of antithrombin III, the appearance rate of amidolytic active thrombin, ${ }^{1} v_{\mathrm{r}}$, will vary as a function of time, $t$, during prothrombin activation according to

$$
\left(v_{\mathrm{r}}\right)_{t}=\left(v_{\mathrm{a}}\right)_{t}-\left(v_{\mathrm{i}}\right)_{t}
$$

where $\left(v_{\mathrm{a}}\right)_{t}$ is the velocity of thrombin generation at time $t$ and $\left(v_{\mathrm{i}}\right)_{t}$ is the velocity of the antithrombin $\mathrm{III} /$ thrombin reaction at time $t$. In all experiments, the initial antithrombin III concentration was significantly greater than the protease concentrations, so that the protease/antithrombin III reaction followed pseudo-first-order kinetics over the time course studied. Thus, when at any interval prothrombin activation is blocked, $\left(v_{\mathrm{i}}\right)_{t}$ can be calculated by multiplying the observed pseudo-first-order rate constant of the antithrombin III/ thrombin reaction by the thrombin concentration.

It is important to note that the antithrombin III/protease reaction is a two-step reaction. The reversible interaction between antithrombin III and thrombin $\left(K_{\mathrm{d}}=1.4 \times 10^{-3} \mathrm{M}\right.$ in the absence of heparin) is followed by a conversion into a stable antithrombin III/thrombin complex, resulting in the inactivation of thrombin, $k=10.4 \mathrm{~s}^{-1}$ (Olson \& Shore, 1982). Thus, the reaction can be analyzed by pseudo-first-order kinetics only when both the antithrombin III and protease concentrations are far below the $K_{\mathrm{d}}$ value. This condition holds for our heparin-free experiments.

The pseudo-first-order rate constant of the antithrombin III/factor $\mathrm{X}_{\mathrm{a}}$ reaction can be obtained when $\left(v_{\mathrm{a}}\right)_{t}$ is plotted exponentially vs. $t$. The velocity of thrombin generation, $v_{\mathrm{a}}$, at time $t$ was calculated from eq 1 . The appearance rate of amidolytic active thrombin, $v_{\mathrm{r}}$, at time $t$ was determined from the slope of the thrombin generation curve at time $t$.

The same mathematical method was used for analysis of the data from the heparin-dependent reactions. Again, the pseudo-first-order approach will only work if the thrombin concentration remains far below its saturation value (Griffith, 1983). Because the thrombin saturation values of the heparin-dependent reaction, as reported in the literature, range from less than $2 \mathrm{nM}$ (Pletcher \& Nelsestuen, 1982) to $4 \mu \mathrm{M}$ (Olson \& Shore, 1982), we performed an independent determination of thrombin saturation under our own conditions. In separate experiments, prothrombin activation in the presence of heparin and antithrombin III was stopped at different time intervals by the addition of soybean trypsin inhibitor. Samples were taken and assayed for residual thrombin activity. Thus, the inhibition of thrombin could be studied at fixed antithrombin III and heparin concentrations but varying thrombin concentrations.

Electrophoretic Blotting Procedure. Proteins were subjected to slab gel electrophoresis in the presence of sodium dodecyl sulfate as described by Laemmli (1970). The proteins were then transferred to nitrocellulose sheets according to the procedure described by Towbin et al. (1979). The electro-

\footnotetext{
1 "Amidolytic active thrombin" or "thrombin activity" is used throughout this paper to indicate that this activity is not necessarily identical with the formation of $\alpha$-thrombin.
} 
Table I: Conditions of Prothrombin Activation ${ }^{2}$

\begin{tabular}{|c|c|c|c|c|c|}
\hline \multicolumn{4}{|c|}{ comp of prothrombinase complex } & \multirow{2}{*}{$\begin{array}{c}\text { prothrombin } \\
\text { conen } \\
(\mu \mathrm{M})\end{array}$} & \multirow{2}{*}{$\begin{array}{l}\text { rate of } \\
\text { thrombin formation } \\
\left(\mathrm{II}_{\mathrm{a}} \min ^{-1} \mathrm{X}_{\mathrm{a}}^{-1}\right)\end{array}$} \\
\hline $\begin{array}{l}\mathrm{FX}_{\mathrm{a}} \\
(\mathrm{nM})\end{array}$ & $\begin{array}{r}\mathrm{FV}_{\mathrm{a}} \\
(\mathrm{nM})\end{array}$ & $\begin{array}{c}\text { phospholipid } \\
(\mu \mathrm{M})\end{array}$ & $\begin{array}{l}\mathrm{Ca}^{2+} \\
(\mathrm{mM})\end{array}$ & & \\
\hline 0.003 & 0.1 & 10 & 5 & 1.0 & 2000 \\
\hline 1.5 & 20.0 & & 5 & 6.0 & 2 \\
\hline 4.0 & & 5 & 10 & 0.5 & 0.6 \\
\hline
\end{tabular}

${ }^{a}$ The reactions were performed in a buffer containing $0.05 \mathrm{M}$ Tris $/ 0.175 \mathrm{M} \mathrm{NaCl} / 0.5 \mathrm{mg}$ of human serum albumin $/ \mathrm{mL}, \mathrm{pH} 7.9$ at $37{ }^{\circ} \mathrm{C}$. Abbreviations: $\mathrm{FX}_{\mathrm{a}}$, factor $\mathrm{X}_{\mathrm{a}} ; \mathrm{FV}_{\mathrm{a}}$, factor $\mathrm{V}_{\mathrm{a}}$.

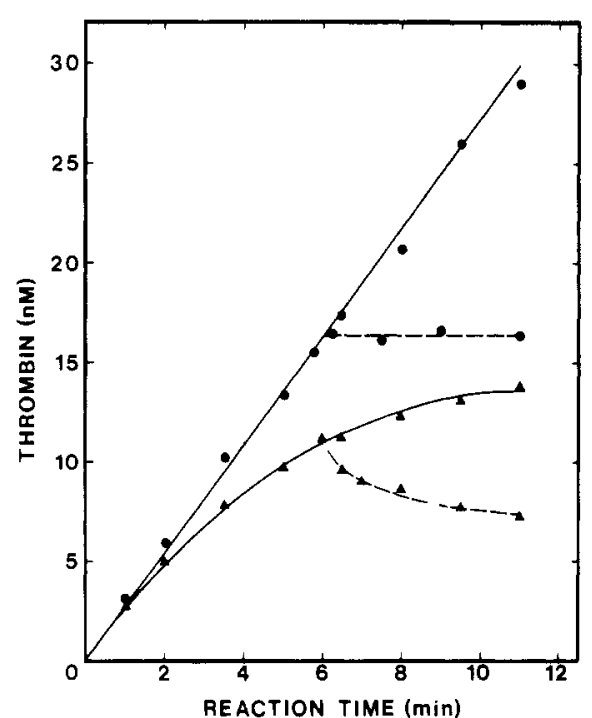

FIGURE 1: Inhibition of thrombin formation and thrombin activity in prothrombin activation mixtures by antithrombin III. Prothrombin $(0.5 \mu \mathrm{M})$ was activated by factor $\mathrm{X}_{\mathrm{a}}(4.0 \mathrm{nM}) /$ phospholipid $(5$ $\mu \mathrm{M} / \mathrm{CaCl}_{2}(10 \mathrm{mM})$ either in the absence $(\mathbf{)})$ or in the presence $(\boldsymbol{A})$ of $100 \mathrm{nM}$ antithrombin III. At timed intervals, samples were taken and assayed for thrombin activity. In separate experiments, soybean trypsin inhibitor $(20 \mu \mathrm{g} / \mathrm{mL})$ was added 6 min after starting the reaction with factor $X_{a}$. The time courses of thrombin activity are indicated by the dashed lines.

phoretic blots were soaked in $0.1 \%$ bovine serum albumin and $0.05 \%$ Tween in phosphate-buffered saline. In essence, the immunological detection of antithrombin III and antithrombin III/protease complexes was performed as described by Towbin et al. (1979). The first antiserum was rabbit antihuman antithrombin III (Sigma). We used horseradish peroxidase conjugated swine anti-rabbit IgG (Dakopatts, Denmark) as an indicator. For the color reaction, the blots were soaked in a solution of $0.5 \mathrm{mg}$ of diaminobenzidine tetrahydrochloride $/ \mathrm{mL}$ (Fluka) and $0.01 \% \mathrm{H}_{2} \mathrm{O}_{2}$ in $0.05 \mathrm{M}$ Tris- $\mathrm{HCl}$, $\mathrm{pH}$ 7.5. This solution was freshly prepared and filtered before use.

\section{RESULTS}

Activation of Prothrombin to Thrombin in the Presence of Antithrombin III. The experimental conditions of prothrombin activation that were used to study the inhibitory action of antithrombin III are summarized in Table $I$. The reactions were initiated by the addition of factor $\mathrm{X}_{\mathrm{a}}$. Under all conditions, the rate of thrombin formation was proportional to the factor $\mathrm{X}_{\mathrm{a}}$ concentration, and when performed in the $\mathrm{ab}$ sence of antithrombin III linear during the time of the experiment.

In the presence of antithrombin III, the rate of appearance of thrombin activity decreased in time. We assumed that this was due to the inactivation of factor $X_{a}$ and the inhibition of thrombin activity. A typical curve is shown in Figure 1.

To distinguish between the antithrombin III action on thrombin and that on factor $\mathrm{X}_{\mathrm{a}}$, we inactivated factor $\mathrm{X}_{\mathrm{a}}$ by

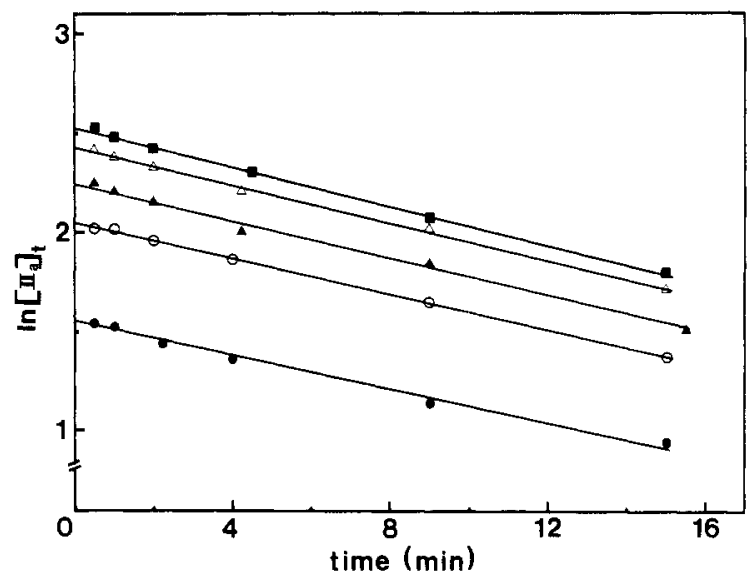

FIGURE 2: Pseudo-first-order plots of inhibition of thrombin activity in prothrombin activation mixtures by antithrombin III. Conditions of prothrombin activation in the presence of antithrombin III were as given in Figure 1. After the addition of soybean trypsin inhibitor, samples were taken and assayed for residual thrombin activity. The expressions are various time intervals of addition of soybean trypsin

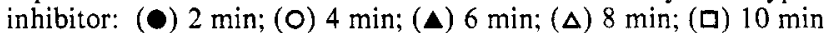

soybean trypsin inhibitor. Thus, by preventing further thrombin formation, the inhibition of thrombin activity can be studied separately. As shown in Figure 1, soybean trypsin inhibitor instantaneously and completely inhibited thrombin production, whereas it had no effect on thrombin activity (upper curve). When soybean trypsin inhibitor was added at timed intervals after the start of prothrombin activation in the presence of antithrombin III, the decrease in thrombin activity is solely due to the antithrombin III/thrombin reaction (lower curve). As shown in Figure 2, the reaction followed apparent first-order kinetics. We found that the pseudo-first-order rate constants of inhibition of thrombin activity $\left(k^{\prime}=0.04 \mathrm{~min}^{-1}\right)$ did not vary with the stage of thrombin production. Knowing the rate constant of inhibition of thrombin activity, we can calculate the rate of inhibition of thrombin at any known concentration of thrombin, i.e., at any point of the curve of thrombin activity vs. time. From the same curve, the rate of appearance of thrombin activity can be determined from the slope at time $t$. The sum of this rate and the rate of disappearance gives the actual rate of prothrombin activation at any point of the thrombin generation curve. The latter then is a true measure for the residual factor $X_{a}$ activity at time $t$ (Figure 3). From an exponentional plot of the rate of prothrombin activation (prothrombinase activity) vs. time, the pseudo-first-order rate constant of inhibition of factor $\mathrm{X}_{\mathrm{a}}$ by antithrombin III can be estimated (Figure 3, inset).

Inhibition of Thrombin Activity in Prothrombin Activation Mixtures. Rate constants of inhibition of thrombin activity were determined after blocking prothrombin activation by soybean trypsin inhibitor (see Figures 1 and 2). The dependency of the pseudo-first-order rate constant of inhibition of thrombin activity on the antithrombin III concentration under different conditions of prothrombin activation is shown in Figure 4. The second-order-rate constants of inhibition are 


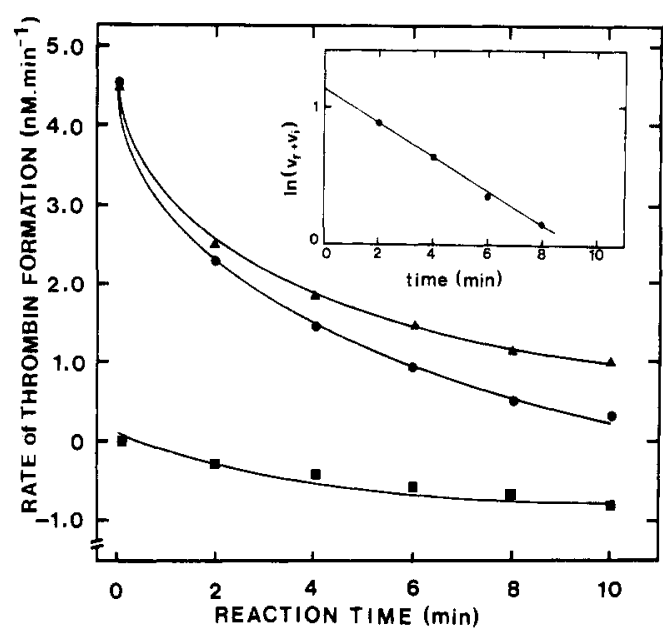

FIGURE 3: Rate of thrombin formation in the presence of antithrombin III. Prothrombin activation in the presence of $100 \mathrm{nM}$ antithrombin III was carried out as described in Figure 1. The rate of thrombin formation $\left(\boldsymbol{e}, v_{\mathrm{r}}\right)$ was calculated from the slope of the thrombin generation curve at the times indicated on the horizontal axis. The rate of thrombin formation, $v_{\mathrm{r}}$, corrected for the rate of thrombin inactivation $\left(\square, v_{\mathrm{i}}\right)$ is depicted by the closed triangles $\left(v_{\mathrm{a}}\right)$. The inset to the figure shows the exponential plot of $v_{\mathrm{a}}$ vs. the prothrombin activation time.

Table II: Second-Order Rate Constants of Inhibition of Factor $\mathrm{X}_{\mathrm{a}}$ and Thrombin by Antithrombin III

\begin{tabular}{|c|c|c|}
\hline \multirow[b]{2}{*}{ condition } & \multicolumn{2}{|c|}{$\begin{array}{c}\text { second-order rate } \\
\text { constant }{ }^{a}\left(\mathrm{M}^{-1} \text { min }^{-1}\right)\end{array}$} \\
\hline & thrombin & factor $X_{a}$ \\
\hline $\begin{array}{l}\text { free proteases } \\
\alpha \text {-thrombin plus added components } \\
\text { prothrombin activation }^{b}\end{array}$ & $\begin{array}{l}19.0 \times 10^{5} \\
20.0 \times 10^{5}\end{array}$ & $11.0 \times 10^{5}$ \\
\hline $\begin{array}{l}\mathrm{X}_{\mathrm{a}} / \mathrm{V}_{\mathrm{a}} / \mathrm{PL}^{d} \\
\mathrm{X}_{\mathrm{a}} / \mathrm{V}_{\mathrm{a}} \\
\mathrm{X}_{\mathrm{a}} / \mathrm{PL}\end{array}$ & $\begin{array}{l}4.3 \times 10^{5} \\
4.4 \times 10^{5} \\
4.9 \times 10^{5}\end{array}$ & $\begin{array}{r}1.3 \times 10^{5} \\
11.0 \times 10^{5} \\
12.0 \times 10^{5}\end{array}$ \\
\hline
\end{tabular}

${ }^{a}$ The second-order rate constants were determined as described under Materials and Methods. ${ }^{b}$ Inhibition of $\alpha$-thrombin in the presence of prothrombin activation reactants. "The conditions of prothrombin activation were as listed in Table I. The rate constants are given for the inhibition of the thrombin activity formed during prothrombin activation and for factor $\mathrm{X}_{\mathrm{a}}$ as part of the prothrombinase complex. ${ }^{d} \mathrm{PL}$, phospholipid.

listed in Table II. Under the different conditions of prothrombin activation, we measured identical rate constants of inhibition $\left(4.5 \times 10^{5} \mathrm{M}^{-1} \mathrm{~min}^{-1}\right)$. However, the rate constants were markedly reduced when compared with the inhibition of $\alpha$-thrombin $\left(1.9 \times 10^{6} \mathrm{M}^{-1} \mathrm{~min}^{-1}\right)$.

It might be questioned whether the prothrombin activation reactants (e.g., factor $\mathrm{V}_{\mathrm{a}}$, phospholipid, $\mathrm{Ca}^{2+}$, and prothrombin) caused the reduced rate of inhibition of thrombin activity. To this end, pure $\alpha$-thrombin ( $10 \mathrm{nM}$ ) was added to a mixture containing factor $X_{a}(3 \mathrm{pM})$, factor $V_{a}(0.1 \mathrm{nM})$, phospholipid $(10 \mu \mathrm{M}), \mathrm{Ca}^{2+}(5 \mathrm{mM})$, prothrombin $(1 \mu \mathrm{M})$, and soybean trypsin inhibitor $(20 \mu \mathrm{g} / \mathrm{mL})$. Because of the presence of soybean trypsin inhibitor, no thrombin formation occurred. After an incubation of $5 \mathrm{~min}$ at $37^{\circ} \mathrm{C}$, antithrombin III was added, and samples were taken at different time intervals to determine residual $\alpha$-thrombin activity. The antithrombin III concentration varied between 50 and $300 \mathrm{nM}$. The second-order rate constant of inhibition of $\alpha$-thrombin under these conditions was found to be $2.0 \times 10^{6} \mathrm{M}^{-1} \mathrm{~min}^{-1}$, indicating that the prothrombin activation components had no effect on the rate constant of inhibition (Table II).

Inhibition of Factor $X_{\mathrm{a}}$ in Prothrombin Activation Mixtures. Following the aforementioned procedure (see Figure 3), in-

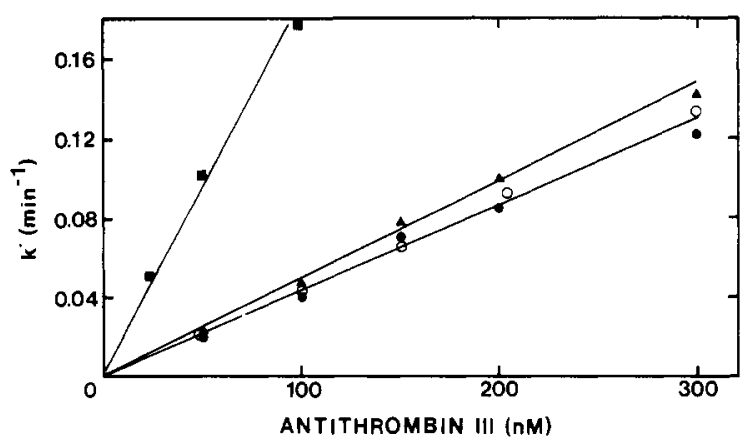

FIGURE 4: Pseudo-first-order rate constant of inhibition of thrombin activity as a function of antithrombin III concentration. Prothrombin was activated by $(\bullet)$ factor $\mathrm{X}_{\mathrm{a}} /$ factor $\mathrm{V}_{\mathrm{a}}$ /phospholipid $/ \mathrm{Ca}^{2+},(\mathrm{O})$ factor $\mathrm{X}_{\mathrm{a}} /$ factor $\mathrm{V}_{\mathrm{a}} / \mathrm{Ca}^{2+}$, and $(\boldsymbol{\Lambda})$ factor $\mathrm{X}_{\mathrm{a}} /$ phospholipid $/ \mathrm{Ca}^{2+}$. The concentrations of the reactants are listed in Table I, rows 1,2 , and 3 , respectively. Antithrombin III was present at various concentrations. The pseudo-first-order rate constants of inhibition of thrombin activity were determined as described in Figure 2. The pseudo-first-order rate constant of inhibition of $\alpha$-thrombin ( $\mathbf{a})$ was determined as described under Materials and Methods.

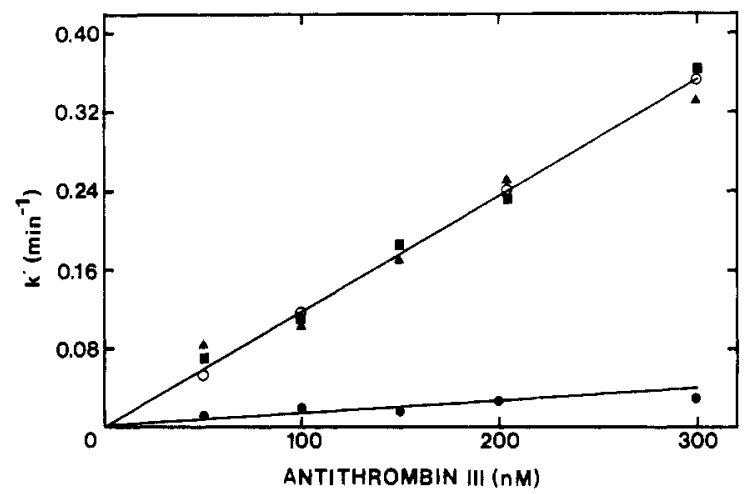

FIGURE 5: Pseudo-first-order rate constant of inhibition of factor $X_{a}$ as a function of antithrombin III concentration. Prothrombin was activated by $(\bullet)$ factor $\mathrm{X}_{\mathrm{a}} /$ factor $\mathrm{V}_{\mathrm{a}}$ /phospholipid/ $\mathrm{Ca}^{2+}$, (O) factor $\mathrm{X}_{\mathrm{a}} /$ factor $\mathrm{V}_{\mathrm{a}} / \mathrm{Ca}^{2+}$, and $(\boldsymbol{\Delta})$ factor $\mathrm{X}_{\mathrm{a}} /$ phospholipid/Ca ${ }^{2+}$. The concentrations of the various reaction components are listed in Table I, rows 1,2 , and 3 , respectively. The pseudo-first-order rate constant of inhibition of factor $X_{\mathrm{a}}$ was determined as described in Figure 3. The pseudo-first-order rate constants of inhibition of free factor $X_{a}$ (a) were determined as described under Materials and Methods.

hibition of factor $\mathrm{X}_{\mathrm{a}}$ by antithrombin III was studied in prothrombin activation mixtures of different composition. In addition, the antithrombin III concentration was varied between 50 and $300 \mathrm{nM}$ in order to obtain the second-order rate constant of inhibition of factor $\mathrm{X}_{\mathrm{a}}$ under these conditions.

The dependency of the pseudo-first-order rate constant of inhibition of factor $X_{a}$ under the different conditions of prothrombin activation on the antithrombin III concentration is shown in Figure 5. The validity of our measuring system is indicated by the observed linear relationships. In addition, the first-order plots extrapolated to within $10 \%$ of the rate of thrombin formation in the absence of antithrombin III (Figure 3 , inset). The second-order rate constants are listed in Table II. When compared with the second-order rate constant of inhibition of factor $X_{a}$ alone, as assayed with the synthetic peptide substrate $S-2337$, it is clearly shown that the inhibition of factor $\mathrm{X}_{\mathrm{a}}$ is reduced only when both factor $\mathrm{V}_{\mathrm{a}}$ and phospholipid were present. No reduction of factor $X_{a}$ inhibition was found when prothrombin activation was performed in the presence of phospholipid and at a prothrombin concentration of $0.5 \mu \mathrm{M}$, i.e., about 25 -fold the $K_{\mathrm{m}}$ value. It is apparent that under these conditions, prothrombin is not a competitive inhibitor of the factor $X_{a} /$ antithrombin III reaction. Also, when factor $\mathrm{V}_{\mathrm{a}}$ and phospholipid were present, the second-order rate 


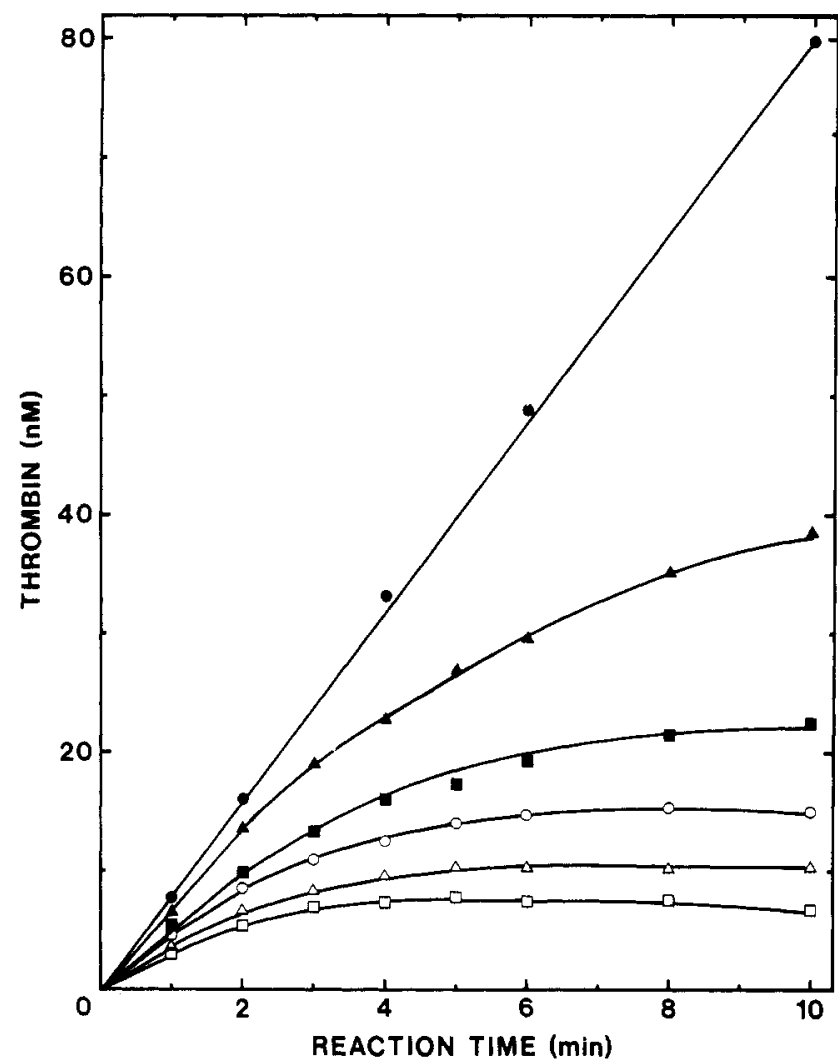

FIGURE 6: Effect of heparin on thrombin generation in the presence of antithrombin III. Prothrombin $(1.0 \mu \mathrm{M})$ was activated by $3 \mathrm{pM}$ factor $X_{a}, 0.1 \mathrm{nM}$ factor $V_{a}, 10 \mu \mathrm{M}$ phospholipid, and $5 \mathrm{mM} \mathrm{Ca}^{2+}$ in the absence (-) or presence of $200 \mathrm{nM}$ antithrombin III and no heparin $(\Delta)$ or heparin at $100(\mathbb{\Delta}), 200(0), 300(\Delta)$, and $500 \mathrm{ng} / \mathrm{mL}$ (ם).

constant of inhibition of factor $\mathrm{X}_{\mathrm{a}}$ was found to be independent of the prothrombin concentration when varied between below and above the $K_{\mathrm{m}}$ (data not shown).

Heparin-Dependent Inhibition of Thrombin and Factor $X_{\mathrm{a}}$ during Prothrombin Activation. Prothrombin $(1 \mu \mathrm{M})$ was activated by factor $X_{a}(3 \mathrm{pM})$, factor $V_{a}(0.1 \mathrm{nM})$, phospholipid $(10 \mu \mathrm{M})$, and $\mathrm{Ca}^{2+}(5 \mathrm{mM})$ in the presence of 200 nM antithrombin III and varying amounts of heparin (Figure 6). The generation of thrombin activity decreased with increasing amounts of heparin as might be expected from a heparin concentration dependent stimulation of both the factor $\mathrm{X}_{\mathrm{a}}$ /antithrombin III and thrombin/antithrombin III reaction.

The heparin-dependent inhibition of thrombin was assessed as described for the heparin-free system (see Figure 2). Thus, soybean trypsin inhibitor was added at different time intervals after the prothrombin activation was started in the presence of antithrombin III and heparin and the thrombin disappearance was measured during an additional 16-min period.

Figure 7 shows the results of a typical experiment performed in the presence of $100 \mathrm{ng}$ of heparin/mL. Each data point is the average ( $\mathrm{SD}=3 \%$ ) of the residual thrombin activity as a percentage of the thrombin activity originally present at the time of addition of soybean trypsin inhibitor. As shown in the inset (Figure 7), the reaction followed pseudo-first-order kinetics, and the apparent pseudo-first-order rate constant of inhibition of thrombin was independent of the initial thrombin concentration when varied between 5.2 and $22 \mathrm{nM}$. Thus, the stage of thrombin production in the presence of heparin had no effect on the $k^{\prime}$ values at the time when the latter assay was made. It is our conclusion that under our conditions the pseudo-first order approach is useful and valid for the heparin-containing reaction system.

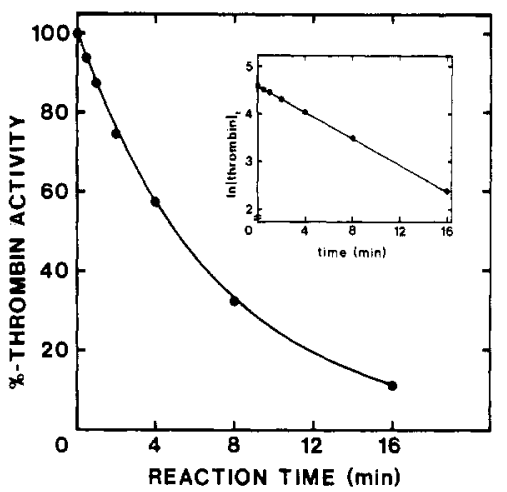

FIGURE 7: Disappearance of thrombin activity after blocking the prothrombinase activity at different stages of thrombin generation. Prothrombin was activated under the conditions of Figure 6 in the presence of $200 \mathrm{nM}$ antithrombin III and $100 \mathrm{ng}$ of heparin $/ \mathrm{mL}$. Prothrombin activation was stopped by adding soybean trypsin inhibitor $(20 \mu \mathrm{g} / \mathrm{mL})$ at $1,2,4$, and $10 \mathrm{~min}$ after the reaction was initiated. Initial thrombin concentrations were $6,9,15$, and $20 \mathrm{nM}$, respectively. Residual thrombin activity was assayed during an additional $16-\mathrm{min}$ period and given as the percentage of the initial thrombin activity.

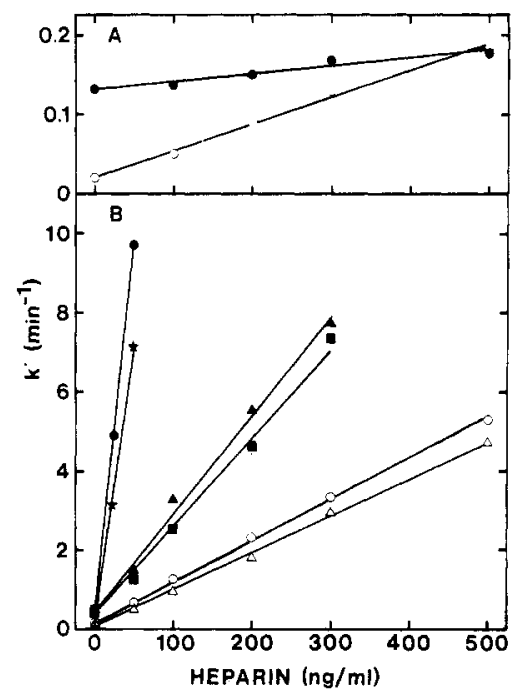

FIGURE 8: Pseudo-first-order rate constant of inhibition of thrombin and factor $\mathrm{X}_{\mathrm{a}}$ activity by antithrombin III $(200 \mathrm{nM})$ as a function of heparin concentration. (A) Inhibition of the prothrombinase activity $(O)$ and of formed thrombin $(\bullet)$. The reaction conditions were as given in Figure 6. (B) Inhibition of $12 \mathrm{nM}$ factor $\mathrm{X}_{\mathrm{a}}(0), 5 \mathrm{nM}$ $\alpha$-thrombin ( $)$, and $22 \mathrm{nM} \alpha$-thrombin ( $\star$ ) in the absence of added prothrombinase components and prothrombin. Inhibition of $12 \mathrm{nM}$ factor $X_{\mathrm{a}}(\Delta), 5 \mathrm{nM} \alpha$-thrombin ( $\left.\Delta\right)$, and $22 \mathrm{nM} \alpha$-thrombin $(\boldsymbol{\square})$ in the presence of $1 \mu \mathrm{M}$ prothrombin, $5 \mathrm{mM} \mathrm{Ca}^{2+}, 10 \mu \mathrm{M}$ phospholipid, and $0.1 \mathrm{nM}$ factor $V_{a}$. The pseudo-first-order rate constants were determined as described under Materials and Methods.

Figure $8 \mathrm{~A}$ depicts the apparent pseudo-first-order rate constant of the inhibition of thrombin, which is directly formed by the prothrombinase complex, as a function of the heparin concentration. Surprisingly, under these conditions the thrombin/antithrombin III reaction is hardly stimulated by heparin. The rate constant when normalized to heparin at 1 $\mu \mathrm{g} / \mathrm{mL}$ was $0.1 \mathrm{~min}^{-1}$.

One explanation that might account for the absence of a heparin effect is that some of the prothrombin activation components remove heparin from the thrombin/antithrombin III reaction. Therefore, we have determined the pseudofirst-order rate constant of inhibition of purified $\alpha$-thrombin ( 5 and $22 \mathrm{nM}$ ) in a mixture containing $1.0 \mu \mathrm{M}$ prothrombin, $0.1 \mathrm{nM}$ factor $\mathrm{V}_{\mathrm{a}}, 10 \mu \mathrm{M}$ phospholipid, $5 \mathrm{mM} \mathrm{Ca}^{2+}$, and varying amounts of heparin. Under all conditions the reactions, followed for at least $80 \%$, showed pseudo-first-order kinetics. Figure $8 \mathrm{~B}$ shows that the prothrombinase components 
and prothrombin reduced the heparin-stimulating effect about 7 -fold. When normalized to heparin at $1 \mu \mathrm{g} / \mathrm{mL}$, the rate constants were 180 and $25 \mathrm{~min}^{-1}$ in the absence or presence of added prothrombin and prothrombinase components, respectively. It appeared that prothrombin made the major contribution to this phenomenon. However, a 250-fold difference was observed between the stimulating effect of heparin on the $\alpha$-thrombin/antithrombin III reaction in the presence of added components and the prothrombinase-formed thrombin/antithrombin III reaction. As shown later, this discrepancy is explained by the formation of meizothrombin, rather than $\alpha$-thrombin, as the major product of prothrombin activation under our conditions.

Because we found that in the heparin-containing reaction the apparent first-order rate constant of inhibition of thrombin was independent of the thrombin concentration, as already demonstrated for the heparin-free reaction, the same mathematical method was performed for the analysis of the heparin-dependent antithrombin III/factor $\mathrm{X}_{\mathrm{a}}$ reactions during prothrombin activation. When the heparin concentration was varied between 50 and $500 \mathrm{ng} / \mathrm{mL}$ at a fixed antithrombin III concentration ( $200 \mathrm{nM})$, the apparent pseudo-first-order rate constant of inhibition of prothrombinase activity increased linearly with the heparin concentration (Figure 8A). Under the same conditions, we determined the apparent pseudofirst-order rate constant of inhibition of free factor $\mathrm{X}_{\mathrm{a}}$ (Figure 8B). It appears that factor $X_{a}$ in the prothrombinase complex is greatly protected from inhibition by the heparin-dependent reaction. The pseudo-first-order rate constant, normalized to heparin at $1 \mu \mathrm{g} / \mathrm{mL}$, was $0.33 \mathrm{~min}^{-1}$, whereas the normalized rate constant for the free factor $\mathrm{X}_{\mathrm{a}}$ /antithrombin III reaction, either in the absence or in the presence of $1 \mu \mathrm{M}$ prothrombin, was $9.5 \mathrm{~min}^{-1}$.

Identification of the Molecular Species with Thrombin Activity during Prothrombin Activation. It has been reported that prothrombin fragment 2 reduced the rate of inhibition of thrombin by antithrombin III about 3-fold. The secondorder rate constants for antithrombin III mediated inhibition of thrombin in the presence of saturating amounts of fragment 2 and antithrombin III mediated inhibition of meizothrombin (des fragment 1) appeared to be identical (Walker \& Esmon, 1979b). Therefore, our results showing a reduced rate of inhibition of thrombin activity could be explained by the presence of prothrombin activation products fragment 1.2 and/or fragment 2. Another interesting possibility might be the formation of meizothrombin as an intermediate in prothrombin activation (Rosing et al., 1986). In order to establish the presence of different molecular species with thrombin activity at nanomolar concentrations, we used the following procedure. At timed intervals, samples were removed from prothrombin activation mixtures containing prothrombin (1.0 $\mu \mathrm{M})$, factor $\mathrm{X}_{\mathrm{a}}(3 \mathrm{pM})$, factor $\mathrm{V}_{\mathrm{a}}(0.1 \mathrm{nM})$, and phospholipid $(10 \mu \mathrm{M})$. The samples were incubated with antithrombin III $(1 \mu \mathrm{M})$ and heparin $(1 \mu \mathrm{g} / \mathrm{mL})$ at $37^{\circ} \mathrm{C}$ for $10 \mathrm{~min}$, i.e., sufficiently to obtain complete inhibition of thrombin activity. Subsequently, the samples were analyzed by polyacrylamide gel electrophoresis in the presence of sodium dodecyl sulfate followed by a blotting procedure and detection of antithrombin III by antibodies conjugated with peroxidase as described under Materials and Methods. The results are shown in Figure 9. In addition to a heavily stained band, comigrating with the large excess of free antithrombin III, two antithrombin III containing complexes are visualized: a major band comigrating with the meizothrombin (des fragment 1)/antithrombin III complex $\left(M_{\mathrm{r}} 110000\right)$ and a minor band co-

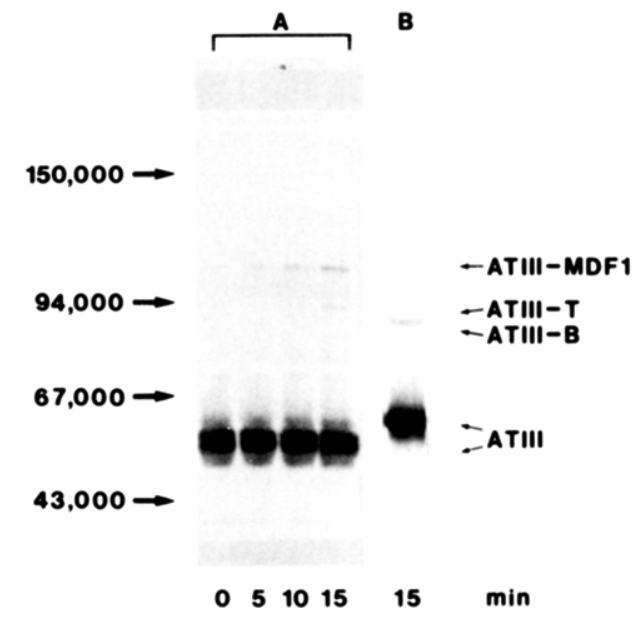

FIGURE 9: Identification of molecular species with thrombin activity in the prothrombin activation mixture. Prothrombin $(1.0 \mu \mathrm{M})$ was activated by $3 \mathrm{pM}$ factor $\mathrm{X}_{\mathrm{a}} / 0.1 \mathrm{nM}$ factor $\mathrm{V}_{\mathrm{a}} / 10 \mu \mathrm{M}$ phospholipid $/ 5$ $\mathrm{mM} \mathrm{CaCl}$. Samples were removed at the times indicated, incubated with antithrombin III $(1 \mu \mathrm{M})$ and heparin $(1 \mu \mathrm{g} / \mathrm{mL})$, and subjected to sodium dodecyl sulfate gel electrophoresis. (A) Unreduced samples; (B) disulfide-reduced sample. Abbreviations: ATIII, antithrombin III; MDF1, meizothrombin (des fragment 1); T, $\alpha$-thrombin; B, B chain of $\alpha$-thrombin. Experimental details are given under Materials and Methods.

migrating with $\alpha$-thrombin/antithrombin III complex $\left(M_{\mathrm{r}}\right.$ $91000)$. Upon reduction, the two antithrombin III containing complexes were found at a position that corresponds to that of the thrombin B-chain/antithrombin III complex $\left(M_{\mathrm{r}}\right.$ 75000). We conclude that the major product of prothrombin activation under initial rate conditions was meizothrombin (des fragment 1).

\section{Discussion}

In the present paper, we report the results of a study on the inhibition of factor $\mathrm{X}_{\mathrm{a}}$ and thrombin by antithrombin III/ heparin. Whereas other studies have used a synthetic peptide substrate or prothrombin to measure residual factor $\mathrm{X}_{\mathrm{a}}$ activity, our approach was to study factor $\mathrm{X}_{\mathrm{a}}$ inactivation under its actual working conditions, i.e., during prothrombin activation. An interesting advantage of this approach is that the effects of the reaction constituents like factor $V_{a}$, phospholipid, and prothrombin (activation products) can be studied simultaneously on both the inactivation of factor $\mathrm{X}_{\mathrm{a}}$ and the inhibition of thrombin activity.

Inhibition of Factor $X_{\mathrm{a}}$. Our experiments show that when prothrombin activation occurs at a phospholipid surface in the absence of factor $\mathrm{V}_{\mathrm{a}}$, factor $\mathrm{X}_{\mathrm{a}}$ is not protected from inactivation by antithrombin III. Under this condition, the second-order rate constant of inhibition of factor $\mathrm{X}_{\mathrm{a}}$ was found to be $1.2 \times 10^{6} \mathrm{M}^{-1} \mathrm{~min}^{-1}$ which is identical with the rate constant of inhibition of factor $\mathrm{X}_{\mathrm{a}}$ alone as measured with a synthetic peptide substrate (Table II). Because in the absence of phospholipid factor $\mathrm{V}_{\mathrm{a}}$ did not protect factor $\mathrm{X}_{\mathrm{a}}$ from inactivation either, it is evident that protection must arise from the formation of the phospholipid-bound factor $\mathrm{X}_{\mathrm{a}}$ / factor $\mathrm{V}_{\mathrm{a}}$ complex.

Ellis et al. (1984) concluded that "the protective effect is probably due to the factor $\mathrm{V}_{\mathrm{a}}$ that altered the binding of factor $\mathrm{X}_{\mathrm{a}}$ on the phospholipid surface in such a way that the steric hindrance to antithrombin III binding is increased, with the large bulk of the factor $\mathrm{V}_{\mathrm{a}}$ molecule perhaps contributing to this effect". Walker and Esmon (1979a) came to the same conclusion. Ellis et al. (1984) reasoned that since their assay only determined phospholipid-bound factor $\mathrm{X}_{\mathrm{a}}$ and not free factor $X_{a}$, they have determined the kinetics of inhibition of 
phospholipid-bound factor $\mathrm{X}_{\mathrm{a}}$. Obviously, this can only be true if during the time of the experiment phospholipid-bound factor $X_{a}$ did not exchange with free factor $X_{a}$. We note that this assumption is probably irreconcilable or incompatible with the current knowledge of both the equilibrium and dynamic properties of the factor $\mathrm{X}_{\mathrm{a}}$ / phospholipid interaction [see Wei et al. (1981), Pusey \& Nelsestuen (1984), and references cited therein]. Therefore, it is highly unlikely that Ellis et al. (1984) have solely monitored the inhibition of phospholipid-bound factor $X_{a}$.

Our data support this notion. Using previously reported factor $\mathrm{X}_{\mathrm{a}}$ /phospholipid binding parameters (Nelsestuen \& Broderius, 1977; van de Waart et al., 1983), it can be calculated that under our conditions of prothrombin activation in the presence of phospholipid the amount of factor $X_{a}$ bound to phospholipid was at least $50 \%$ of the total amount of factor $\mathrm{X}_{\mathrm{a}}$ present. In addition to the $K_{\mathrm{m}}$ values for prothrombin in the presence or absence of phospholipid being 0.02 and 100 $\mu \mathrm{M}$ (van Rijn et al., 1984), respectively, we can calculate that because prothrombin was present at a concentration of $0.5 \mu \mathrm{M}$, all phospholipid-bound factor $X_{a}$ is saturated with substrate, whereas in solution the amount of factor $X_{a}$ /prothrombin complexes is negligible. Therefore, our assay virtually measures the thrombin formation by the factor $X_{a}$ bound to the phospholipid surface only. It is worth noting that synthetic peptide substrates at concentrations above their $K_{\mathrm{m}}$ value have been reported to compete with antithrombin III for factor $\mathrm{X}_{\mathrm{a}}$ (Ceustermans et al., 1982). Thus, when factor $X_{a}$ is saturated with prothrombin, we might expect to find such a competitive action of prothrombin in the factor $\mathrm{X}_{\mathrm{a}}$ /antithrombin III reaction. However, the second-order rate constant of factor $X_{a}$ inactivation by antithrombin III during prothrombin activation in the presence of phospholipid was the same as that determined for free factor $X_{a}$ (Table II). This observation, together with the known data on the kinetics of the factor $\mathrm{X}_{\mathrm{a}}$ / phospholipid interaction, strongly indicates that the hypotheses and conclusions of Ellis et al. (1984) are untenable. That is, the effect of phospholipid on the kinetics of inhibition of factor $\mathrm{X}_{\mathrm{a}}$ by antithrombin III cannot be explained by assuming that the enzymatic properties toward antithrombin III are altered when factor $X_{a}$ is bound to the phospholipid surface. However, because of the rapid kinetics of the factor $X_{a} /$ phospholipid interaction, the inhibition of free factor $X_{a}$ has to be considered as well. In this respect, it is important to note the following.

Pusey et al. $(1982,1984)$ demonstrated that factor $\mathrm{X}_{\mathrm{a}}$ has a very marked effect on the rate of dissociation of factor $V_{a}$ from a phospholipid surface. The most likely explanation for this effect is that because of the tight association between the two phospholipid-bound proteins (Lindhout et al., 1982) a complex is produced with two membrane association sites. The overall result is a markedly reduced rate of dissociation of both factor $V_{a}$ and factor $X_{a}$ from the phospholipid surface. Therefore, the protection of factor $X_{a}$ from inhibition by antithrombin III when both factor $\mathrm{V}_{\mathrm{a}}$ and phospholipid are present might be caused by the reduced rate of dissociation of factor $\mathrm{X}_{\mathrm{a}}$ from the phospholipid surface.

In conclusion, our results argue strongly for a competition for factor $\mathrm{X}_{\mathrm{a}}$ between a phospholipid surface and antithrombin III in solution. It is feasible that protection of factor $X_{a}$ from inhibition by antithrombin III depends on both the rate of inhibition of factor $X_{a}$ in solution and the rate of dissociation of factor $X_{a}$ from the phospholipid surface.

Inhibition of Thrombin. The second aim of this study was to reveal whether or not the kinetics of inhibition of $\alpha$-thrombin differ from those of inhibition of thrombin activity formed during the initial phase of prothrombin activation. There has been a report on the effect of prothrombin fragment 2 on the inhibition of $\alpha$-thrombin by antithrombin III (Walker \& Esmon, 1979b). In addition, recent work from our laboratory has indicated that during the initial phase of prothrombin activation by factor $X_{\mathrm{a}}$ prothrombin is mainly cleaved between $\mathrm{Arg}_{323}$ and $\mathrm{Ile}_{324}$, resulting in amidolytic-active meizothrombin (Rosing et al., 1986). We found that the second-order rate constant of inhibition of $\alpha$-thrombin by antithrombin III was about 4 times the rate constant of thrombin activity in the prothrombin activation mixtures and independent of the composition of the prothrombinase complex. Walker and Esmon (1979b) reported that fragment 2 was found to slow down the rate of inhibition of $\alpha$-thrombin about 3 -fold. Therefore, the presence of fragment 2 and/or fragment 1.2 in our activation mixtures might be a plausible explanation for our findings. An alternative explanation is the formation of meizothrombin, because covalently and noncovalently linking of fragment 2 to thrombin gave the same second-order rate constants of inhibition (Walker \& Esmon, 1979b). Therefore, we analyzed our activation mixtures for the presence of meizothrombin. As shown, a considerable amount of meizothrombin (des fragment 1) was detected (Figure 9). Because meizothrombin appeared to be the main product under the conditions used, it can be questioned whether pure $\alpha$-thrombin can be used as a standard to measure the reaction product of prothrombin activation. However, on the basis of functional molar concentrations as assessed by active-site titration of meizothrombin preparations obtained by the activation of prothrombin by Echis carinatus venom and $\alpha$ thrombin preparations, we found no differences between the reactivity of $\alpha$-thrombin and meizothrombin toward the synthetic peptide substrate $\mathrm{S}-2238$.

Intriguing is the observation that when heparin is studied in prothrombin activation mixtures, it had hardly any effect on the inhibition of thrombin activity by antithrombin III. We ruled out that this phenomenon was solely caused by the heparin binding properties of prothrombin. As yet, it remains to be established to what extent and in which mode fragment 2 and/or fragment 1.2 either covalently or noncovalently bound to $\alpha$-thrombin affects the interaction between heparin and thrombin. Recently, we initiated a study on the interaction between meizothrombin and heparin. Our preliminary results indicate that in contrast to $\alpha$-thrombin, meizothrombin is unable to bind heparin.

\section{ACKNOWLEDGMENTS}

We are grateful to Dr. Hans Soons for assistance with the electrophoretic blotting procedure and to Dr. Jan Rosing for reading and criticizing the manuscript.

Registry No. DMPC, 4235-95-4; DOPS, 4004-05-1; blood coagulation factor $\mathrm{Xa}$, 9002-05-5; blood coagulation factor $\mathrm{Va}, 65522-14-7$; meizothrombin, 69346-19-6; prothrombin, 9001-26-7; thrombin, 9002-04-4; antithrombin, 9000-94-6; heparin, 9005-49-6.

\section{REFERENCES}

Ceustermans, R., Hoylaerts, M., de Mol, M., \& Collen, D. (1982) J. Biol. Chem. 257, 3401-3408.

Comfurius, P., \& Zwaal, R. F. A. (1977) Biochim. Biophys. Acta 488, 36-42.

de Kruijff, B., Cullis, P. R., \& Radda, G. K. (1975) Biochim. Biophys. Acta 406, 6-20.

Ellis, V., Scully, M. F., \& Kakkar, V. V. (1984) Biochemistry $23,5882-5887$.

Griffith, M. J. (1983) Proc. Natl. Acad. Sci. U.S.A. 80, 5460-5464. 
Laemmli, U. K. (1970) Nature (London) 227, 680-685.

Lindhout, T., Govers-Riemslag, J. W. P., van de Waart, P., Hemker, H. C., \& Rosing, J. (1982) Biochemistry 21, 5494-5503.

Marciniak, E. (1973) Br. J. Haematol. 24, 391-400.

Nelsestuen, G. L., \& Broderius, M. (1977) Biochemistry 16, 4172-4177.

Olson, S. T., \& Shore, J. D. (1982) J. Biol. Chem. 257, 14891-14895.

Pletcher, C. H., \& Nelsestuen, G. L. (1982) J. Biol. Chem. 258, 5342-5345.

Pusey, M. L., \& Nelsestuen, G. L. (1984) Biochemistry 23, 6202-6210.

Pusey, M. L., Mayer, L. D., Wei, G. J., Bloomfield, V. A., \& Nelsestuen, G. L. (1982) Biochemistry 21, 5262-5268.

Rosenberg, R. D. (1982) in Hemostasis and Thrombosis: Basic Principles and Clinical Practice (Colman, R. W., Hirsch, J., Marder, V. J., \& Salzman, G. E. W., Eds.) pp
962-985, J. B. Lippincott, Philadelphia, PA.

Rosing, J., Zwaal, R. F. A., \& Tans, G. (1986) J. Biol. Chem. 261, 4224-4228.

Thaler, E., \& Schmer, G. (1975) Br. J. Haematol. 31, 233-243.

Towbin, H., Staehelin, T., \& Gordon, J. (1979) Proc. Natl. Acad. Sci. U.S.A. 76, 4350-4354.

van de Waart, P., Bruls, H., Hemker, H. C., \& Lindhout, T. (1983) Biochemistry 22, 2427-2432.

van Rijn, J. L. M. L., Govers-Riemslag, J. W. P., Zwaal, R. F. A., \& Rosing, J. (1984) Biochemistry 23, 4557-4564.

Walker, F. J., \& Esmon, C. T. (1979a) Biochem. Biophys. Res. Commun. 90, 641-647.

Walker, F. J., \& Esmon, C. T. (1979b) J. Biol. Chem. 254, 5618-5622.

Wei, G. L., Bloomfield, V. A., Resnick, R. M., \& Nelsestuen, G. L. (1982) Biochemistry 21, 1949-1959.

\title{
Analysis of the Self-Association of Human Red Cell Spectrin
}

\author{
F. Shahbakhti and W. B. Gratzer* \\ Medical Research Council Cell Biophysics Unit, King's College, 26-29 Drury Lane, London WC2B 5RL, U.K. \\ Received March 19, 1986; Revised Manuscript Received June 12, 1986
}

\begin{abstract}
The self-association equilibrium of spectrin has been studied by separating the molecular species present in the cooled reaction mixture by gel electrophoresis. The association constant for formation of the hexamer from dimer and tetramer is lower by an order of magnitude than that for the association of two dimers. The association constant for the formation of the octamer from the hexamer is appreciably larger, and the value appears to reach a constant level for higher oligomers. These observations are explained in terms of conformational strain due to formation of cyclic structures, the distortion being greatest on passing from the tetramer to the hexamer. The association for a single-site interaction between the dimer and a univalent fragment has also been analyzed. The results show that the free energy generated by a single-point interaction is much greater than that obtained by averaging over all pairwise interactions within the oligomers, correcting for the effect of cratic entropy. The results are related to the association state of the spectrin prevailing in the cell. Phosphorylation at the physiological sites in the dimer does not appreciably change the thermodynamics of self-association, at least up to the hexamer.
\end{abstract}

\begin{abstract}
Qpectrin, the major protein of the membrane cytoskeleton in red cells, is constructed of heterodimers. The two chains, $\alpha$ and $\beta$, are resolved in gel electrophoresis in the presence of sodium dodecyl sulfate (SDS) ${ }^{1}$ into a doublet with molecular weights of about 250000 and 230000 . The two components differ in sequence but show extensive homologies, both being made up of not fully identical repeating units (Speicher \& Marchesi, 1984). The dimer is an elongated, somewhat flexible structure, with a length in the electron microscope of $100 \mathrm{~nm}$ (Shotton et al., 1979). The dimers will undergo self-association in a head-to-head manner (Ungewickell \& Gratzer, 1978) to give a tetramer 200-nm long (Shotton et al., 1979). The tetramer is the form predominantly present in the cell, and its interconversion with the dimer is characterized by a high
\end{abstract}

${ }^{1}$ Abbreviations: SDS, sodium dodecyl sulfate; HEPES, $\mathrm{N}-(2-$ hydroxyethyl)piperazine- $N^{\prime}$-2-ethanesulfonic acid; EDTA, ethylenediaminetetraacetic acid; Tris, tris(hydroxymethyl)aminomethane; Bicine, $N, N$-bis(2-hydroxyethyl)glycine. activation energy (Ungewickell \& Gratzer, 1978). Thus the reaction proceeds on a time scale of minutes to hours at a temperature of $30^{\circ} \mathrm{C}$ or more, whereas below about $20^{\circ} \mathrm{C}$ there is no measurable change over a period of many days.

Later work showed that, at sufficiently high spectrin concentrations, higher oligomeric forms than the tetramer are generated (Morrow \& Marchesi, 1981; Morrow et al., 1981) and indeed occur in the cell (Tyler et al., 1980; Morrow \& Marchesi, 1981; Nermut, 1981; Liu et al., 1984). It could be inferred, and electron microscopy showed (Tyler et al., 1980; Liu et al., 1984), that the higher oligomers are formed not by end-to-end association, but by branching; that is to say, each constituent dimer is bound at the end that carries the association sites to two separate dimer partners. This is in structural terms an unusual situation, for it implies that the chains can deform without a prohibitive cost in strain energy to allow a correct apposition of binding sites. The thermodynamic characteristics of this system are analzyed here and must be supposed to relate to the function of spectrin in the 